\title{
Human Rights Discourse on Migration - THe CASe of Slovakia
}

\begin{abstract}
Human rights discourse is one of the discourses relevant in the political discursive struggle over the migration and migration policies in particular nation states or in the European Union. Traditionally, in Western European immigration countries, this discourse has been represented by leftist political parties (socialist or social democratic) and in a more radical way by the social movements and human rights NGO's. In Slovakia, human rights discourse on migration has never been significantly represented by relevant political parties, on the contrary, migration has been always a topic marked by considerable and unusual political consensus. Human right discourse on migration is a marginal view, represented mainly by few non-governmental organizations. Using the method of Critical discourse analysis, the paper tries to analyse the strategies of discursive struggle over the migration, and relevant social representations being used.
\end{abstract}

KeYwORDs: human rights, Slovakia, migration, politic, non-governmental organization

\section{INTRODUCTION}

Globalization has played an important role in expanding human rights standards throughout the world. In general, human rights are rights that belong to a person simply because he/she is a human being. They are equal and inalienable. Human rights should therefore be universal, however their support and protection is not universal. The legitimacy of human rights 
standards is generally accepted and the aim of the international community is to socialize dissenting states to institutionalize these principles. The rights of migrants in the context of human rights standards are a highly controversial topic. For this reason, human rights discourse on the rights of migrants can be said to be an anti-hegemonic discourse, oriented against the status quo as it focuses on rights that are not generally accepted. Power-position of the human-rights discourse on migration is thus very ambivalent. On one hand it can appeal to the generally accepted notion of human rights, on the other hand, human-rights of migrants are not sufficiently codified in the national or international law and often contradict other legal principles (citizenship, right of the state to control who can enter its territory). Also in practice, the implementation of these principles can contradict other principles and values (most often the need of the state to ensure the security of its citizens).

Human-rights discourse is one of the key discourses that constitutes migration discursive field in global, European, as well as on the national level. I will analyse human-rights discourse on migration in Slovakia, where it has a specific, but rather marginal position. The general methodological frame of my paper is so called discourse analysis. The most important theoretical and methodological assumption of discourse analysis is that language as a discourse creates performative effects in the social reality. It is to say that words may significantly change and influence the non-language world of social practice. Language is thus not only the description of a social practice but it is the social practice itself. Through the analysis of the language it is thus possible to reconstruct the meaning of the social action. It is not to say that the non-language practice can be revealed solely through the language practice and that it is reducible to it. To analyse discourse means for me to search for the rules that constitute social practice: to analyse why, how and where do these rules apply. This is not possible without analysis of the language - relevant texts shaping this practice, but always it is important to take into account the non-language institutional practice. Then we can say that the discourse is the whole of the meanings forming the rationality of the social action. It means certain frameworks of rules that specify which things are good, correct, true and meaningful. This approach is typical for example, for Mouffe and Laclau's (2001) theory of discourse, but as well for 
Michel Foucault (2006). In my paper I analyse important political strategic documents of Slovak Republic in area of migration, materials of relevant nongovernmental organisations (e.g. their web pages, publications, brochures) and as well I conducted several interview with representatives of these NGO's. The relevant period of my analysis is from 2007 when Slovakia entered the Schengen Union.

The discourse analysis in connection to migration is quite examined topic in the social sciences. Most authors have payed attention to the analysis of so called security discourse and securitization of migration (e.g. Buonfino, 2004; Huysmans, 2000; Bigo, 2002a, 2002b and others). Identification and further analysis of so called human-rights discourse on migration from the discourse analysis perspective is not that common. This is due to the fact that theoreticians of discourse analysis often come out from a critical perspective directly stemming from the defence of human rights (see e.g. Wodak, Meyer, 2009). There are, of course, some critical analyses of human rights discourse, but not so often in relation to migration. For example, ethnographic criticism according to which the human rights perspective is a eurocentrist view of the world (Pollis, Schwab, 1980). Other authors emphasize that human rights discourse reduces its objects to the victims that the "civilized" West is supposed to take care which depoliticizes and silences their own political demands (Brown, 2004). A similar argument is used by A. Sczepanik (2009) in her analysis of the functioning of NGOs assisting refugees in the Czech Republic. Some sociologists have further criticized the fact that human rights are often studied too abstractly, only in the legal scope (Estévez, 2012).

\section{HUMAN RIGHTS DISCOURSE ON MIGRATION AS A COUNTER-HEGEMONIC DISCOURSE}

As we have already mentioned, the legitimacy of certain human rights standards is considered to be non-problematic, the international community guides the observance of these rights, the governments of significant part of the world accept these rights at least in the rhetoric (although there may be a violation of these rights in the practice). The interpretation of what is or is not a violation of such a human rights standard may differ to a certain extent, but there is a certain consensus, and in the extreme cases, there is an arbitrator 
who decides that is officially accepted (e.g. the European Court of Human Rights). Basok (2009) calls these human rights as hegemonic human rights norms: "Hegemonic human rights norms are congruent with liberal notions of formal equality between individuals and individual freedom from coercion, as well as principles of national sovereignty while counter-hegemonic human rights values are the ones that in one way or another challenge the status quo, either by undermining the political economic foundations of liberal democracies and/or the principles of national sovereignty" (Brysk, In Basok, 2009, p. 187). Human rights standards have become widely accepted if they: "resonated with such principles of modernity as equality, protection of vulnerable groups, relying on existing principles, based on transformative historical moments and being defended with comprehensible and persuasive key moral actors" (Ibidem).

An example of human rights discourse that goes beyond the level of hegemonic human rights standards is the United Nations Convention on the Protection of the Rights of All Migrant Workers and Members of Their Families, which by defining (albeit with restrictions) the rights of undocumented migrants represents a challenge to the Westphalian principles of the organization of the world. A stronger representative of this type of discourse is the so-called discourse of the "open borders" or the idea of a world without borders, advocated by some academics, non-governmental organizations, and left-wing social movements. Basok (2009) introduces three notions of the discourse of open borders. The most conservative variant supports human right to migrate and have access to a limited set of rights in the target country, but does not emphasize the automatic right to naturalization. Ottonelli (In Basok, 2009, p. 189) opposes restrictive immigration measures and emphasizes the right of people to form their social relations with other people freely while accepting structural limits of rights for non-citizens. The most radical version of the discourse of "open borders" calls for the unlimited right of people to move and receive economic and social benefits (Düvell, 2003, Jordan and Düvell, 2003, In Basok, 2009). This approach is based on the idea of global forms of governance where social rights will be guaranteed to everyone on the principle of "global" or "cosmopolitan" citizenship. The third, central position recognizes the legitimacy of the national state to restrict 
the economic and social rights of its citizens, but advocates the freedom of movement and the right of all migrants to become citizens (Bauböck, 1994, Carens 1987, 2000 In Basok 2009, p. 190).

According to Fraser (2005, p. 84), migrants' advocates invoke a postWestphalian principle, and thus seek "to change the very grammar of framesetting - and thereby to reconstruct the meta-political foundations of justice for a globalizing world". These ideas being anti-hegemonic do not attract the attention of politicians and have a minimal impact on social and political practice. Organizations and activists fighting for migrants rights from this perspective however often rely on the arguments coming out from the recognized human rights principles and other acceptable arguments. They thus come to some contradiction between the ideological background of their goals and the ways in which they are pursued. Basok (2009) pointed out the situation of activists in her research of Canadian and American activists fighting for migrant rights. In advocating migrants' rights they must refer to rules and principles that are anchored in the law or regarded as legitimate, even though they regard them as principally wrong. For example, they point to the economic benefits of these migrants, although they don't see the economic benefits as principal argument.

Chandler (2002, p. 1) emphasizes that human rights discourse appears to go beyond the liberal democratic framework to aspire to a broader normative project of human progress, which celebrates the universal nature of humanity. This radical aspiration is reflected through the development of a human-centred approach to global questions, putting the value of human dignity above the search for economic gain or the narrow interests of particular national governments. According to Chandler, human rights discourse contains three key principles that make it possible to believe that it can potentially make a radical change of the principles of functioning of the international community. Firstly, it is the principle of universality, secondly, the idea of empowering those who do not have the power and to active support of those who are, for various reasons, in a minority position (individuals, ethnic minorities or excluded groups in society). And thirdly, it is a human-oriented approach in which the principles of ethics and morality are more important than certain ideologies or political schemes like the right 
or the left. While politics is perceived as an expression of interests or rivalry of ideas, human rights add legitimacy to institutional consensus and the fact that they are perceived as expressing altruism and collective values of the moral community, expressing a certain moral consensus (Ibidem, p. 7).

On the other hand, in practice, we can meet with what we might call the occupation or emptying of human rights discourse. Appealing to human rights has become a natural part of the political language. The consensus on human rights (in their generally recognized form) has made them a natural part of political documents and language. A part of the political spectrum is even very active in defending human rights principles, but most often it touches only recognized hegemonic human rights standards. Human rights discourse is adopted by national governments, non-governmental organizations or the media. As Chandler (2002, p. 2) reminds, the prioritization of human rights issues has changed the language and institutional practice of international relations. International organizations, including the United Nations, NATO, the International Monetary Fund, or the World Bank, it means - including those whose mandates seem to have nothing in common with human rights, have learned to use the language of human rights. However, according to a number of critiques, in this form human rights discourse is losing its radical charge and instead of calling for political and economic inequalities within the international system, it rather helps re-establish new hierarchies, controls and regulations.

\section{Human Rights Discourse in Slovakia}

In Slovakia as well referring to human rights of migrants and advocating their respect is part of government policies and documents. The rights of migrants are included in a special chapter of the National Strategy for the Protection and Promotion of Human Rights in the Slovak Republic where it is stated: "All migrants have the same rights, including economic, social and cultural rights that cannot be denied by their nationality or migration status" (Government of Slovak Republic, 2009). At the same time, the document highlights the "prohibition of discrimination which ensures equal protection for both nationals and foreign nationals... there are few exceptions to the principle of non-discrimination, such as the right to vote and to be elected and 
the right to enter and reside in the country" (ibidem). The cited formulations fully point to the precariousness of migrants rights. On the one hand, human rights are guaranteed to all migrants "irrespective of their legal status", but on the other hand they do not guarantee the most basic - the right of residence in a country which is itself a precondition for the exercise of any other rights. This concerns migrants' residence on the territory of the state but also their legal status. "The legislation on the acquisition of nationality is one of the exclusive powers of EU Member States" (ibidem). And this means that civil status, which is itself a condition for the full realization of human rights in a nation state, is not guaranteed by international agreements or EU law.

The reference to respect for human rights standards and commitments is, of course, part of all key migration documents of Slovak Republic. The strategic document Migration Policy of the Slovak Republic with a view to 2020 states that "in accordance with its international obligations, the Slovak Republic effectively combats all forms of illegal migration, taking into account the human rights aspects associated with this phenomenon" (MV, 2011). Such a "chronic" repetition of phrases like "complying with international commitments" or "respecting human rights obligations" in official documents or laws, with the absence of deeper attention devoted to the human rights aspects, leads in fact to the emptying of these concepts. Human rights are explicitly mentioned in these documents very rarely, which evoke only some necessary compliance with the minimum standards to which the Slovak Republic has committed not an active defence of these principles. The expressions of respect for international human rights obligations often indicate rather proudness that the Slovak Republic is able to comply with these international obligations than the interest in contents and meaning of these international commitments.

The discourse of the official documents or laws may in some circumstances be understood and interpreted as a discourse of the state, as its official position or attitude. On the other hand, it should be remembered that the state is composed of a plurality of actors. The state is government, state officials, individual departments, state-owned organizations, courts, and so on. And here we naturally find differences concerning the position of human rights issues. Part of these differences is associated with a certain position or function 
of the institution within the political system and state administration. For example, we find significant difference between the Ministry of the Interior and the Ministry of Labour, Social Affairs and Family. While the first one is more oriented on security and thus prioritizes these questions, the second one appeals to the human rights principles more frequently and intensively. The state has also formed institutions whose direct competence is to watch on the observance of human rights. These are the Institute of the Ombudsman and the Slovak National Centre for Human Rights.

Slovak National Centre for Human Rights is a National Human Rights Institution (NHRI), which is defined as an independent institution, but it is established by the state, and political nominees are members of the main board of the organization. The NHRI also acts as a national anti-discrimination body, so called "equality body" established under the EU law to observe the compliance of the principle of equal treatment irrespective of race or ethnic origin and gender, age, sexual orientation, religion, belief, and disability. The NHRI provides information on the existence of anti-discrimination laws and informs about the possibility to take legal action and to seek redress or compensation for an act of discrimination, but also provides direct assistance to people who have been victims of discrimination. (www.snslp.sk) From this point of view, migrants and foreigners living in Slovakia can also be NHRI clients. At the same time, the Centre is devoted to the development of various monitoring and evaluation reports and so-called Alternative Report on the Implementation of the Convention on the Elimination of All Forms of Racial Discrimination, where it also touches, although only partially, the migration issues. While it cannot be said that NHRI is addressing migration and migrants in a fundamental way, it is an organization that can both critically address the politicians and state actors (and occasionally it does so) and the same time directly represent migrants (as victims of discrimination). Another state authority whose competencies directly affect the surveillance of human rights is the Ombudsman. In the recent past, Slovak Ombudsman Jana Dubovcová filed a lawsuit to the Constitutional Court of the Slovak Republic due to the non-compliance of some provisions of the Act on Asylum and the Alien Residence Act with the Constitution of the Slovak Republic and some other international conventions. 
It means the above-mentioned state actors sometimes take a critical position towards other state institutions or their representatives coming out from the rationality of human rights discourse. The state institution are however often seen as not enough rigorous and are often the target of criticism of non-governmental human rights organizations. In 2011, for example, the Centre for Research on Ethnicity and Culture (CVEK) criticized the above mentioned actors for passivity: "It is alarming that public authorities, especially the Minister for Human Rights, National Minorities and Gender Equality, the Public Defender of Rights and the Slovak National Centre For human rights, whose role is the protection and promotion of human rights did not publicly and vigorously refuse to introduce such a policy of the Minister of Interior. It is sad that the Prime Minister, who has been working on this topic for a long time, did not refuse that either. There is no doubt that the rejection of a discriminatory and degrading policy is not politically attractive. Respect for human rights, however, must be guaranteed for all, not only for »ordinary citizens", but also (and especially) for those who live in the periphery of society and differ from the majority and of what is considered "normal «". This commentary concerns Roma not migrants, but in this example, it is visible that the criticism from non-governmental organizations is often coming out of a human rights position and is very resolute.

Apart from the differences within the state institutions, there are some differences within the political spectrum, however not so obvious as it could be expected. Generally speaking, Slovak politicians do not use the argumentative basis of human rights discourse, and thus we don 't find significant differences among political parties like we know them from the Western countries, where leftist or liberal parties most often use the argumentative basis of human rights discourse. In Slovakia none of the political parties can be described as "pro-migratory", but there are also some exceptions, e.g. in case of some politicians from the political parties representing the Hungarian minority.

To conclude, everyone is talking about the human rights. But some of the actors just appeal to human rights rhetorically and it is easy to convict them of the contradictions - when proclaimed universality is in contrast with the subsequent particularity. Others speak the language of human rights because they have to do so due to their position or function - they more or less often 
point to these contradictions and to the non-observance of human rights standards. And there are also others who are attacking the first ones and criticize the others for the lack of vigour and activity. It should be said that these misunderstandings are based on a different conceptions of human rights. One part of the actors and institutions relies on the legal notion of human rights. As a result, they react only when the law is broken, but this reaction is not always proactive, not all of these actors interpret their duty as active observance of human rights. They do not necessarily act initiatively in case of doubt whether there was a violation of human rights principles or not, and they are waiting for judgment by legal experts or courts. From the point of view of those who define their role as an active defence of human rights, the former ones seem to be passive and slack. Active defenders try to act initiatively and pay attention to human rights violations even when it is unclear whether this is a contradiction with a legal norm. These "proactive" actors most often include various non-governmental organizations, activists or human rights experts.

In the following part, I will analyse only human rights discourse in the narrower sense of the word - it means a discourse that prioritises human rights in the way that human rights should be the starting point and limit of every action. This means that any action that interferes with the human rights of anyone is not permissible, violation or limitation of human rights is not permitted under any circumstances and nothing can take priority over them. To ensure human rights, maximum effort must be concentrated, and in practice their maximum not minimum concept and standard should be applied. In migratory practice in Slovakia, two variants of human rights discourse can be identified: humanitarian discourse, which promotes the idea of active help especially to the most vulnerable groups of migrants - refugees, displaced persons, unaccompanied minors, and illegal migrants whose (often basic) human rights have been violated and critical multicultural discourse, based on active resistance to racism, ethnocentrism and other phenomena that lead to the powering of a majority and which bring cultural, ethnic and other minorities into subordinate positions. The basis of critical multicultural discourse is not only belief in the equality of all cultures (and therefore in the universality of humanity as in humanitarian discourse), but also the idea of mutual enrichment of cultures and thus the positives of cultural mixing. 


\section{Humanitarian Discourse}

Humanitarian discourse is a variant of human rights discourse, which focuses mainly on the gross violations of fundamental human rights. In the centre of its attention there are persons migrating as a result of "push" factors, it means forced migrants. These include refugees in particular. The expansion of humanitarian discourse is related to the modern history of asylum law that began to form before the Second World War (in connection with the influx of Russian refugees during the revolution in 1917), but a major impetus for its development was the experience with the massive displacement of the population as a result of the Second World War. For this purpose, the Office of the United Nations High Commissioner for Refugees was established. Its mandate should have been temporary at first, but further events (such as refugee waves after the Revolution in 1956 in Hungary, or the 1960s' waves of immigrants from Africa during the decolonization period) showed its necessity also in modern post-war history. Humanitarian discourse thus focuses mainly on the defence of the right to asylum. Although the basis of this right is individual political persecution, there has been some partial widening of its definition for example on the cases of ecological or humanitarian disaster. It can therefore be said that humanitarian discourse not only focuses on the importance of helping refugees who meet the definition of individual persecution, but in general, to those who are under pressure from any hardships, hunger, war, persecution, etc. and had to leave their homes.

Humanitarian discourse is in its core a secular discourse, but it occurs in an area where various religious-oriented or church organizations operate. It is not just a specific of Slovakia. As Ager \& Ager (2011) emphasize, since the late 19 th century and the 20 th century, the codification of humanitarian principles and humanitarian law has been accompanied by the institutionalization of humanitarian actors by the provision of an exclusively secular humanitarian regime. Organizations with different links to religious tradition remain active in this area, but generally adopt such an approach and discourse that makes it very difficult to distinguish them from secular organizations (Thaut 2009, Hopgood 2010, In Ager \& Ager 2011, p. 457). Such an approach has some advantages for them. It opens cooperation opportunities and provides access to sources of public funding. In the Slovak context, this development dates 
back to the 1990s, when UNHCR started to operate in Slovakia and at the same time organizations with a religious background started to help refugees and asylum seekers. For example, an organization "Slovenská humanitná rada" (The Slovak Humanity Council) is an example of organization who unifies several other organizations in the field when some of them have an obviously religious background, part of them at all.

Organizations reproducing humanitarian discourse often offer direct help and assistance to vulnerable categories of migrants, especially refugees and specific categories like women, children, and older people. This is related to the dominant image of the migrant in humanitarian discourse. Migrants are primarily represented as victims of bad conditions in their home country (war, humanitarian disaster, political persecution, fear, poverty. Migrants are represented primarily as people who did not have any other choice then to escape. The actors reproducing humanitarian discourse are not always in strict compliance with the Geneva Convention and international law, in their argument of the eligibility of migrants to leave their home country. Rather, they try to portray the overall situation of refugees in their home country as bad and critical. It is clear, however, that economic conditions are not highlighted (as they are not legal base for asylum). If these organisations point to a poor economic situation, they present it only as a result of war, persecution, humanitarian disaster, and so on. The dominant motive they highlight is fear. "People leaving their country and their loved ones run away from persecution, oppression and violence that makes them unable to live a full life in their own country" (www.nasiutecenci.sk).

Refugees are portrayed in humanitarian discourse as victims; its actors therefore call for solidarity with people in need. Visual material plays an important role in this. Webpages and other presentation materials of humanitarian organizations contain many photos showing mostly migrants with distinctive cultural and ethnical features. Images of migrants of dark skin are often used. Even if these are not dark-skinned migrants, there are still other features pointing to cultural origin (various artefacts, religious symbols or signs that point to the origin of third world countries: traditional clothing), which, in addition to cultural affiliation, also refers to a lower 
economic status or a critical current social situation. Very common is the display of women and children. If men are shown, they are mostly older ones. The presented profile of migrant or refugee, however, does not much correspond to the reality, and especially the reality in Slovakia, where the large number of asylum seekers are young men of productive age.

Humanitarian discourse uses these images to raise compassion and solidarity, and thus to increase the urgency of their appeal. People who are not economically active (older men or women with small children) are often seen as deserving help, and moreover it evokes that the main goal of these people is to live peacefully and to take care of their children, which is portraying them as peaceful and harmless. Their possible ambitions, economic or political, their self-realisation is secondary in humanitarian discourse. Heather Johnson (2011) talk about the de-politicisation of migrants in humanitarian discourse. She analysed how the character of the visual elements changed and what role they play in the formation of certain specific representations of refugees and migrants in UNHCR campaigns and visuals. Johnson (2011, p. 1016) characterized the change in the image of the refugee over the last 60 years as "a change from the heroic, political individual to a nameless flood of poverty-stricken women and children". While the first concept dominated the Cold War period discourse when a refugee was a man from an industrial society escaping from political reasons, alone or with his nuclear family, whose political individuality was highlighted as it have affirmed the correctness of the Western Bloc's political goals, the second concept is pushing for the image of a third-world refugees who are represented as victims without their own political demands and ambitions. A similar change in the image of the refugee was also identified by Szcepaniková (2009) in her research of clients and NGOs working in the Czech Republic. She claims that migrant women play a specific role in positive representation of refugees. It is perhaps easier to present them as innocent victims who deserve sympathy for the public. But this image may be self-indulgent because it evokes passivity and dependence.

But humanitarian discourse is also trying to show the lives of migrants and refugees here in Slovakia. These images also point to the migrant's difficult fate: "The life of the asylum seeker is very similar to waiting in the waiting room. The uncertain future of the applicant and his family is the biggest concern. 
Everyday life is marked by crowded rooms, language problems and boredom" (www.unhcr-centraleurope.org). On the other hand, in terms of their current lives in Slovakia, it is important to present migrants as ordinary people - as "ones of us" who have their family, dreams and desires and who want to start a normal fully life in Slovakia or in Europe. Therefore, their individual stories and experiences are often presented. The actors of humanitarian discourse are also trying to do activities that would introduce refugees as people like us but also unique ones bringing their cultural customs, artistic skills, traditions. They carry out various leisure activities, markets, bazaars, food tastings, sports events, and so on. These activities are important in terms of mediating contact with the majority, and thus for the integration of migrants. On the other hand, they can be considered stereotypical; showing mainly traditional "folklore" and activities associated with the stereotypical view of these people and promote perception of migrants especially as "kind and exotic". As a result, during the refugee crisis, the public seeing in the media young refugee men with mobile phones or tablet was "shocked" and considered this to be a betrayal and evidence that these are not real refugees. However this visual presentation in traditional way is often accompanied by real assistance and many organizations seek to integrate migrants into the labour market and therefore into modern society.

The basic tool with which humanitarian discourse works is some kind of appeal to the public and political elites. For example, the call word on the main banner of web page "nasiutecenci.sk" (which is the web page of NGO Slovenská humanitná rada) is "because everybody deserves the chance to start over again". However, this call is rather a call to our humanity and solidarity than a request for certain legitimate claims based on a reasoned argumentation. An appeal to humanity and the call for empathy with refugees, and the abovementioned portrayal of migrants and refugees as victims, reinforces this appeal. This is a form of critique that is based on persuasion, in this case, with an appeal to a universal humanity. Criticism here has a form of "loving remembrance of parents for a child" and thus urging other actors to the necessity and need to help. It is a kind of criticism, whose purpose is rather to move people, politicians, towards greater openness and empathy for refugees and migrants. For example, the Slovak Humanitarian Council says: 
"We should remember this period (the period of Communism - the author's note) and understand our moral obligations knowing that our refugees from former Czechoslovakia have been accepted in many countries in the past... If we are that fortunate to find ourselves in a much better life today, it is undoubtedly right and in accordance with the ethics and humanity to try to help people who are under the conditions of oppression, persecution and disobedience" (www.nasiutecenci.sk).

In this discourse, therefore, the non-confrontational criticism plays an essential role. Humanitarian discourse relies on conviction and goodwill of others - Western states, public, and politicians. This may give the impression that it is just on our good will whether we accept these refugees or not. Thus, in its communication with the public, humanitarian discourse relatively weakly communicates the rights and claims of refugees, not only in terms of international law but also in a wider context. On the other hand, what can be accentuated only slightly in external communication is accomplished by the activities. Many organisations in practice collect information about the countries of origin of the asylum seekers in order to be able to argue, if necessary, before the Migration Office decision-makers or before the courts about the eligibility of claims of refugees.

Thus it can be said that the actors of humanitarian discourse try to destabilize the border between the eligible refugee and the so-called bogus refugee. They are aware of the fact that the definition of individual political persecution on the basis of the Geneva Convention is relatively strictly applied into practice in Slovakia. For example, while other countries often grant asylum for humanitarian reasons Slovak offices do so rarely. It should be said, however, that the destabilization of the border between the "right" and the "false" asylum seeker does not take the form of systematic communication with public. It is more likely to be discerned in the very activity of these actors and in their contact with those who are more or less directly involved in the problem.

\section{Critical Multicultural Discourse}

Discourse, which I call here "critical multicultural discourse", does not necessarily have to work with the term multiculturalism, but it is a discourse that highlights the benefits of migration, and mixing of cultures perceives as 
enriching. It is a discourse that has a positive relation to real or possible social and cultural change. Compared to humanitarian discourse, which refers to the universal humanity, emphasizing in particular the fact that migrants are "human beings" like all others, critical multicultural discourse emphasizes the cultural diversity not only as something that should not be an obstacle to the recognition of rights and human approach but as something that is valuable itself that is normal and natural. "Slovakia for all is trying to connect people who are convinced that diversity is natural" (CVEK, undated source). "Migration is a common phenomenon, and it has always been although this is often forgotten in public opinion... 40 years of Communism has shaken completely the natural feeling that people are moving" (CVEK representative, In NMŠ, 2011).

I refer to this discourse as to "critical" because it critically reflects unequal status of migrants and their integration problems in our society. The barriers to their integration sees above all in the setting of our - Slovak society. It is also part of a human rights discourse, as it points to the problem of the application of rights on the basis of migrant status in Slovak society. But while humanitarian discourse focuses on fundamental human rights, such as the right tolife, personal freedom, security, freedom of expression, belief etc., critical multicultural discourse highlights also political and social rights. The requirement for these rights is inherent in critical multicultural discourse, because it is based on a comparison of the status of a migrant with a citizen status.

The main actors of this discourse are primarily non-governmental organizations that profile themselves as pro-migratory, anti-racist and antinationalist and partially other unorganized individual actors - independent analysts, experts, activists. At the same time, it should be emphasized that the organizations that have been mentioned in the previous section as the most typical representatives of humanitarian discourse, in some contexts and situations also reproduce critical multicultural discourse, and vice versa as these discourses complement and support each other rather than compete.

In Europe, various pro-migrant organizations have participated in the politicization of migration and have become an important part of political conflict and struggle over the definition of state, citizenship, human rights in relation to migration. Many times they have advocated specific policies 
in favour of migrants and many times have been successful. Such successes can also be found in Slovakia. For example, the partial improvement of the legislative conditions of so called "foreigners with supplementary protection" was probably also the result of efforts by NGO's who draw attention to the very complicated situation of this vulnerable group of migrants. Pro-migration organizations are active in raising awareness of institutional problems and deficiencies, and actively attack and deconstruct the notion of rationality contained in the discourses they oppose, mainly the security discourse.

The specificity of the situation in Slovakia is the absence of some "natural partners" for pro-migratory NGOs such as trade unions, left-wing political parties and social movements, or migrant communities themselves (which are relatively weak mainly due to the low number of migrants and their internal heterogeneity). Koopmans (2005, p. 206) says that the activity of such organizations can then be understood as a form of "political altruism". At the same time, however, he points out that it is not just an interest-based political altruism, but altruism based on identity. Organizations try to push for a community definition that is based on a certain understanding of the citizenship and the state, and the defence of migrant rights is then part of the struggle for a more inclusive definition of a nation. In this sense, it is not just something that would relate to these "others" but it is something that also relates to "us". One of such organizations explains: "Slovakia for All is an initiative that wants to give new content to the story of Slovakia. It represents a vision of a country in which everyone can feel at home, regardless of their nationality, gender, sexual orientation, social status, language, country of origin or health disability" (CVEK, undated source).

In critical multicultural discourse, migrants are represented as a very diverse category; it means we find more distinct features than common ones. Unlike in humanitarian discourse, where the motivation of migrants based on "push" factors is emphasized; in critical multicultural discourse the positive motivation to migrate plays the role, as well as their positive and constructive role in our society. Migrants are presented as doing business, studying, working, raising children. Their different culture or ethnicity is not related only to traditional way of life, but instead, this discourse shows how can mix with our culture and creates new - "modern" phenomena. The 
positive role of migrants is defined in connection with their specific role - e.g. profession, but also with their cultural specificity, perceived as the potential for cultural enrichment and as an important impetus for opening and changing our Slovak rigid and closed society. "We are convinced that the increasing migration to Slovakia can make a major contribution to redefining what is perceived as "Slovak" and how to see what is "our «" (Ibidem). "Migrants coming from different, often very distinct cultural environments represent a great challenge to this perception of »Slovak", because their inclusion in society requires not only their adaptation to the new conditions given by a different culture, but also a change on the part of the receiving society" (Gallová-Kriglerová, Kadlečíková, Lajčáková, 2009, p. 13).

Different cultural identities of migrants are not perceived as a problem in this discourse. As a problem, the Slovaks' reluctance to accept cultural differences is perceived. The main obstacle to the full realisation of migrant's rights in our country is considered the restrictive approach of state institutions, the reluctance of the authorities, as well as public attitudes. "We can criticize public policy, and I think it is very legitimate, because it does not allow foreigners to become a part of this country, does not provide them information and forces them to rely on their own social networks" (CVEK representative, In NMŠ, 2011).

While in humanitarian discourse there is a space devoted to the migrant himself, his complicated life story or his culture, critical multicultural discourse gives migrants the opportunity to talk (directly or indirectly) about their experiences with life in Slovakia, about contacts with institutions or with the local population. Such experiences of migrants are either spoken by the organizations representatives themselves or give migrants direct opportunity to take part in a discussion, session, documentaries or publications. It has to be said that migrants themselves are often more reticent in their public criticism than NGO representatives and try to talk about both - good and bad experiences. "Sharper" criticism often comes from NGO representatives, who both generalize certain experiences of more migrants, and define criticism as their main role. "We also have the experience unfortunately, I do not know how to statistically evaluate it, so it is from our experience that those who look differently, whether they are Asians or have a darker skin, the 
authorities tend to behave with disrespect. They don't take into account that it might be a university professor, a neurosurgeon, just at the moment a person is degraded to someone who needs the stamp" (Director of IOM, In NMŠ, 2011). In this sense, pro-migration organizations are trying to strengthen the voice of migrants in Slovakia and make them more visible.

While humanitarian discourse have been described here as "nonconfrontational" in its core, critical multicultural discourse on the contrary, may be considered to be more or less confrontational in the sense that it participates in the direct and open criticism of actors who reproduce (primarily) security discourse. This criticism can be concrete or general (for example criticism of a particular measure or criticism of the general approach of the state to migrants) and its dominant motive is the self-reflexions of us as "Slovaks". The representatives of critical multicultural discourse agree that the Slovaks are closed, have difficulties to accept differences, they are full of prejudices and stereotypes. "In the background of how we perceive foreigners is how we perceive ourselves... any difference is perceived as a threat... The statements of politicians in this country are so strongly supporting this construct of the Slovaks as a nation-building ethnic and everything else is than a threat, this way we cannot even be surprised that the public opinion is the way it is" (CVEK representative, In NMŠ, 2011). This statement suggests that the negative setting of Slovaks against cultural differences is often interpreted as a consequence of politicians' behaviour. Thus, the basic definition of the situation in a critical multicultural discourse can be summarized as follows: The Slovaks are quite closed, which is a consequence of the behaviour of politicians; on the other hand, politicians behave that way also because of public opinion as they identify the rhetoric based on fears as beneficial bringing them voices in the elections. As one activist said, "They do not need it". In the sense that politicians do not need to take care of minorities because this cannot bring them political points. Another activist evaluated the situation with the words: "It's a closed circle" (Ibidem).

How then, the multicultural discourse sees a step out of this closed circle? Analysing their activities, it can be said they try to change the public opinion rather than directly intervene in the politics. This is likely to be related to the fact that the actors of critical multicultural discourse, especially NGOs, 
have no potential strong political partners. Form of coercive actions, protests, and open calls to politicians are less-used tools. Campaigns to the public, discussions are used more frequently. One way how to convince the public is not just the reference to migration and cultural diversity as a positive contribution and a natural thing, but also the damasking of politicians and politics. And so also those who are trying to do this, for example in the form of humour and parody, aimed at dismantling the myth of Slovak nationalism and those who represent these myths - politicians or certain social groups can be marked as part of the critical multicultural discourse.

\section{Conclusions}

The security discourse of migration and the resulting restrictive access to migration are very significant in Slovakia (see Androvičová, 2015), and NGOs working in the field of migration identify this as a priority issue they want to tackle. Therefore, they are trying, by various means, to reverse the negative setting of a large part of Slovak society towards migrants and migration. However, the primary positive representation of migration and migrants in this discourse can put a strain on the fact that some migrants, especially migrants from less economically developed countries, are migrating due to economic "push factors", i.e. under the pressure of the poor economic and social situation in the country of their origin and not voluntarily. This is what is lacking in Slovak pro-migration discourse, especially due to the lack of involvement of such actors as left-wing political groups and social movements. If migration is portrayed as natural, this is often overwhelmed by the fact that this "naturalness" results from a certain set of frameworks in which migration is characterized by very low voluntariness and freedom for certain categories of people. Humanitarian discourse reflects push factors, but predominantly non-economic ones while critical multicultural discourse reflects pull factors of various kinds. Economic and ecological push factors, which are relevant both in terms of asylum migration and labour migration, are generally poorly reflected in migratory discourse in Slovakia.

The portrayal of migrants like those who are "on the same ship" with us "poor Slovaks" - (as we often define ourselves - who also often have to go to 
work abroad) could be a productive strategy of changing attitudes towards migration in favour of greater openness and acceptance of foreigners. This partially seems to be the case of Poland. In European comparative studies (e.g. Eurobarometer), Poland is among the countries of Central Europe and the former Eastern bloc, which is the most tolerant and most open to immigrants and immigration, and is above the EU average in polls measuring the attitudes towards immigrants, whereas other Central European and post-socialist countries (including Slovakia and the Czech Republic) are, often significantly, below the average. One of the possible interpretations (although it is not the only possible explanation) is that the inhabitants of Poland are more likely to identify themselves with the immigrants as they are the ones who often migrate for work or study. The moment of identifying a migrant as someone with whom I am or might be one day, or my relatives is probably higher in Poland. It is possible to say that in nowadays societies we are all "potential migrants", each of us carry in a set of assumptions under which circumstances we would be willing or forced to move. Although this is individual and dependent on a number of other factors (e.g. age), such an identification contains a certain idea of solidarity of "us" - potential migrants, which shifts the discursive boundary of "us" vs. „them" - from a predominantly ethnic definition to a definition given by a common position. It is another concept of solidarity which is not primarily national or ethnic.

This is also important in relation to migrants. The category of a migrant is, as Joppke and Morawska (2003) pointed out, also sliceable to other social categories. In Slovakia, there is a lack of cross-section approach in the case of migrants. Particular segments of the society operate many times without awareness of the ethnic or cultural diversity with which they are actually confronted. There are organizations that deal with migrants, but less attention is paid specifically to migrants and foreigners in certain social position - e.g. employees, pupils, unemployed, seniors, etc. Some organizations, at least in some areas, are actively working to change the attitudes of stakeholders (e.g. in the field of education or in the municipal policy), but these were all initiatives by non-governmental organizations, although in cooperation with the competent authorities, it is necessary to say that more involvement of state institutions is needed. 
To be "pro-migratory" therefore should mean not only a celebration of movement and cultural diversity. It should also include practical efforts and steps towards removing the "push" factors of migration - economic, humanitarian, environmental, etc. And it should also mean the effort in migrant integration, attention to removing the obstacles that migrants experience in their everyday lives. However, this cannot be managed by non-governmental organizations, and there is a need for the involvement of other actors, especially public administration and state. This process could avoid strong ethnicization of the public space (Vašečka, 2009), which is of a structural character.

\section{References}

Ager, A., Ager, J. (2011). Faith and the Discourse of Secular Humanitarianism., "Journal of Refugee Studies” 24 (3), p. 456-472. ISSN 0951-6328.

Androvičová, J. (2015). Sekuritizácia migrantov na Slovensku - analýza diskurzu, "In Sociológia" 47 (5), p. 319-333.

Basok, T. (2009). Counter-hegemonic Human Rights Discourses and Migrant Rights Activism in the USA and Kanada, "International Journal of Comparative Sociology" 50 (2), p. 183-205. ISSN 0020-7152.

Bigo, D. (2002a). To Reassure and Protect after September 11th [online]. In Social Science Research Council Essays [cit. 1.7.2012], http://www.ssrc.org/sept11/essays/bigo.htm [access: 20.11.2017].

Bigo, D. (2002b). Security and Immigration: Toward a Critique of the Governmentality of Unease, "Alternatives: Global, Local, Political" 27 (Special Issue), p. 63-92. ISSN 0304-3754.

Brown, W. (2004). "The most we can hope for": Human rights and the politics of fatalism, "South Atlantic Quarterly" 103(2-3), p. 451-463. ISSN 0038-2876.

Buonfino, A. (2004). Between Unity and Plurality: The Politicization and Securitization of the Discourse of Immigration in Europe, "New Political Science" 26 (1), p. 23-48. ISSN 0739-3148.

Chandler, D. (2002). Introduction: Rethinking Human Rights, [in:] D. Chandler (ed.), Rethinking Human Rights Critical Approaches to International Politics, Hampshire, Backingstoke: Pallgrave Macmillan. ISBN 9780333977163.

CVEK. Undated source. Slovensko pre všetkých: naozaj pre všetkých. Memorandum Iniciatívy [online], http://www.cvek.sk/uploaded/files/Slovensko\%20pre\%20 v\%C5\%A1etk\%C3\%BDch_MEMO.pdf [access: 20.11.2017]. 
Huysmans, J. (2000). The European Union and the Securitization of Migration, "Journal of Common Market Studies” 38, p. 751-777. ISSN 1468-5965.

Estevéz, A. (2012). Human Rights, Migration, and Social Conflict: Toward a Decolonized Global Justice, Hampshire, Basingstoke: Palgrave Macmillan ISBN 9780230339449.

Foucault, M. (2006). Rád diskurzu, Bratislava: Agora. ISBN 9788096939435.

Fraser, N. (2005). Reframing Justice in a Globalizing World, "New Left Review" 36, p. 69-88. ISSN 0028-6060.

Gallová-Kriglerová, E., Kadlečíková, J., Lajčáková, J. (2009). Migranti. Nový pohlad na staré problémy. Multikulturalizmus a kultúrna integrácia migrantov na Slovensku [online], Bratislava: CVEK, http://www.cvek.sk/uploaded/files/CVEK_migranti_final.pdf [access: 20.11.2017].

Government of Slovak Republic. (2009). Štatút Riadiaceho výboru pre migráciu a integráciu cudzincov [online], Bratislava: Government of Slovak Republic, https:// lt.justice.gov.sk/.../priloha.rtf [access: 20.11.2017].

Johnson, H.L. (2011). Click to Donate: visual images, constructing victims and imagining the female refugee, "Third World Quarterly" 32 (6), p. 1015-1037. ISSN 0143-6597.

Joppke, C., Morawska, E. (2003). Integrating Immigrants in Liberal Nation-States: Policies and Practices, [in:] C. Joppke, E. Morawska (eds.), Toward Assimilation and Citizenship, Hampshire, Basingstoke: Palgrave Macmillan. ISBN 9781403904911.

Koopmans, R. (2005). Contested Citizenship: Immigration and Cultural Diversity in Europe, Minnesota: University of Minnesota Press. ISBN 9780816646630.

Laclau, E., Mouffe, Ch. (2001). Hegemony and Socialist Strategy: Towards a Radical Democratic Politics, London, New York: Verso. ISBN 9781859843307.

MV. 2011. Migračná politika Slovenskej republikys výhladom do roku 2020 [online], Bratislava: Ministery of Interior, http://www.minv.sk/?zamer-migracnej-politikyslovenskej-republiky [access: 20.11.2017].

NMŠ. 2011. Migranti v centre pozornosti [online], Videoreport of discusion in festival „fúžn“, https://www.youtube.com/watch?v=Whavj0fz_DE [access: 20.11.2017].

Pollis, A., Schwab, P. (1980). Human rights: A western construct with limited applicability, [in:] A. Pollis, P. Schwab (eds.), Human Rights: Cultural and Ideological Perspectives, p. 1-18, New York: Praeger. ISBN 9780030466311. 
Sczepaniková, A. (2009). Mezi státem a klienty - Nevládní neziskové organizace pracující s uprchlíky a migranty $v \check{C} R$ [online], http://aa.ecn.cz/img_upload/224c070 4b7b7746e8a07df9a8b20c098/ASzczepanikova_Mezistatemaklienty.pdf [access: 20.11.2017].

Vašečka, M. (2009). Postoje verejnosti $k$ cudzincom a zahraničnej migrácii v Slovenskej Republike, Bratislava: International Organization for Migration. ISBN 9788097030704 .

www.nasiutecenci.sk [access: 20.11.2017].

www.snslp.sk [access: 20.11.2017].

www.unhcr-centraleurope.org [access: 20.11.2017]. 